\title{
Transformacja energetyki w trybie innowacji przełomowej (TETIP) do elektroprosumeryzmu wehikułem do przyszłości tu i teraz
}

\author{
Transformation of the Energy Sector in the Breakthrough Innovation Mode \\ (TETIP) to Electroprosumerism as a Vehicle for the Future, Here and Now
}

Jan Popczyk

Powszechna Platforma Transformacyjna Energetyki 2050

mail: jan.popczyk@ep2050.pl

ORCID: https://orcid.org/0000-0002-4313-950X

Abstract

This paper is the author's proposal of a coherent concept of a transformation of the entire fossil fuel energy sector to electroprosumerism (an economy without fossil fuels, without nuclear energy also) before 2050. It is a universal concept, but this paper focuses on Poland specifically. This concept of a transformation (in breakthrough, innovation mode) is based on a scientific basis, namely on a paradigmatic triplet, i.e. the following: an eclectic electroprosumer paradigm and two hard paradigms, namely: exergy and virtualization. The concept has three broad dimensions: economic, social and environmental (nature and climate). This concept can be creatively confronted with the EU energy transition plans, and also in the global context (American in the Euro-Atlantic zone and Chinese in the socialist market economy), based on political goals.

Słowa klucze - energy, transformation, electroprosumerism, politics

Niniejszy artykuł jest nieznacznie zmodyfikowaną wersją tekstu prof. Jana Popczyka Transformacja energetyczna TETIP (transformacja energetyki w trybie innowacji przełomowej) do elektroprosumeryzmu wehikułem do przyszłości tu i teraz, zamieszczonego na stronie Powszechnej Platformy Transformacyjnej Energetyki 2050, https://ppte2050.pl/platforman/bzppte/static/uploads/Artyku\%C5\%82\%20ze\%2ostatusem\%20artyku\%C5\%82u\%20S \%C5\%82ownika\%2oencyklopedycznego\%20Elektroprosumeryzmu\%20na\%20PPTE2050.\%20/an\%20Popczyk.pdf. 
Taka będzie energetyka, jakie elektroprosumentów „chowanie” (w ramach zasady subsydiarności, fundamentalnej zasady ustrojowej strefy euroatlantyckiej)

1. Elektroprosument (polski, unijny, strefy euroatlantyckiej) to współczesny odbiorca energii elektrycznej, który indywidualnie realizuje globalne paryskie porozumienie klimatyczne i unijny cel neutralności klimatycznej roku 2050 (odejście od paliw kopalnych), w ramach praktycznych uwarunkowań wytwarzanych przez zasadę pomocniczości (subsydiarności) na każdym poziomie demokratycznej władzy (w szczególności zaś samorządowej, państwowej, unijnej i zinstytucjonalizowanego ładu światowego). W Polsce jest to odbiorca energii elektrycznej: począwszy od zwykłego Kowalskiego w domu jednorodzinnym i w mieszkaniu w budynku wielorodzinnym, po największych odbiorców: przemysłowego (KGHM) i infrastrukturalnego - PKP Energetyka.

2. Każdy polski elektroprosument $w$ trzeciej i dalszych dekadach XXI wieku jest indywidualnym beneficjentem (spadkobierca) uspołecznionych już osiąnnięć:

$1^{\circ}$ - rewolucji przemysłowych w XVIII i XIX wieku, z centralną rolą wielkoskalowej energetyki paliw kopalnych - WEK-PK w tych rewolucjach;

$2^{\circ}$ - elektryfikacji w pierwszych sześciu dekadach XX wieku, z centralną rolą elektroenergetyki, rozwijającej się na początku lokalnie, w trybie „prosumenckim”, w postaci samorządowych elektrowni wodnych oraz przemysłowych elektrowni węglowych, łączonych sukcesywnie - wraz z szybkim wzrostem mocy elektrowni węglowych - w regionalne systemy elektryczne, a następnie w krajowe systemy elektroenergetyczne (SEE) z dominującymi elektrowniami węglowymi, a w szóstej dekadzie już z elektrowniami jądrowymi;

$3^{\circ}$ - cyfryzacji, która rozpoczęła globalny marsz w ostatnich czterech dekadach XX wieku i w wypadku której punkt krytyczny uspołecznienia nastąpił (to jest hipoteza) w roku 2020 i jest związany bezpośrednio z pandemią COVID-19.

3. Równocześnie, będąc beneficjentem, elektroprosument (polski, unijny, strefy euroatlantyckiej) ponosi społeczną odpowiedzialność za negatywne skutki rewolucji przemysłowych, elektryfikacji i cyfryzacji. Negatywne skutki w postaci patologicznego rozwarstwienia społecznego, niepohamowanego konsumpcjonizmu i naruszenia równowagi środowiskowej (tu najważniejszy jest efekt klimatyczny). Czyli ponosi indywidualną (w 
ramach np. rodziny) oraz społeczną odpowiedzialność za przyszłość. Oznacza to własny wkład w zrównoważony rozwój: budowanie przyszłości z wykorzystaniem osiągnięć przeszłości, jednak uwolnionej od jej negatywnych skutków.

4. Indywidualny wkład każdego polskiego elektroprosumenta pierwszej fali elektroprosumeryzmu (nasilającej się już w Polsce) - elektroprosumenta „wsobnego” w zrównoważony rozwój - jest wynikiem jego indywidualnego wysiłku oraz indywidualnych korzyści skonfrontowanych przez mechanizmy konkurencji między schodzącymi rynkami końcowymi (energii elektrycznej, ciepła, paliw transportowych) oraz rynków elektroprosumeryzmu (rynków energii elektrycznej i rynków bezsieciowych urządzeń oraz usług) funkcjonujących w dopełniających się środowiskach - prawnym i subsydiarności - właściwych dla poszczególnych poziomów władzy w Polsce.

5. Subsydiarność na żadnym poziomie władzy nie może oznaczać „narkotycznych” (uzależniających) systemów wsparcia ze strony sił politycznych, nie mających uzasadnienia w trzech wymiarach fundamentalnych podstaw stymulujących dokonująca się zmianę: gospodarczym, społecznym, środowiskowym. Oczywiście systemy takie sa ogólnie domeną populistycznych sił politycznych i autorytarnych (dązących do zniewolenia) mniejszych lub większych części społeczeństwa. Takie siły w elektroprosumeryźmie nie mają racji bytu. Bo nie ma w nim żadnego istotnego miejsca dla tych, którzy musieliby albo chcieli ten populizm finansować. Nie mają też racji bytu ze względu na fakt, że siłą elektroprosumeryzmu jest powszechny dostęp do rynków elektroprosumeryzmu, który z natury rzeczy wymaga wolności (rynkowej) jako wartości fundamentalnej.

6. Wkład pretendenta-innowatora drugiej fali elektroprosumeryzmu (w Polsce wzbierającej) w zrównoważony rozwój jest wkładem charakterystycznym dla nowego „trybu” powstawania innowacji, obejmujących swoimi skutkami cała 3-wymiarowa przestrzeń: gospodarczą, społeczna, środowiskowa. W przestrzeni tej na obecnym etapie innowacje nie są dziełem genialnych jednostek, lecz wynikiem współpracy zespołów interdyscyplinarnych.

7. Zatem w wypadku wkładu pretendenta-innowatora drugiej fali elektroprosumeryzmu bardzo silnymi uwarunkowaniami są: 
$1^{\circ}$ - zespołowość i interdyscyplinarność tego wkładu;

$2^{\circ}$ - jego osadzenie w łańcuchu logicznych następstw wkładów: wielkich uczonych, którzy sformułowali zasady termodynamiki i elektromagnetyzmu; wielkich wynalazców-przedsiębiorców, którzy zapoczątkowali elektryfikację; innowatorówentuzjastów-przedsiębiorców, którzy przeprowadzili rewolucję cyfrową;

$3^{\circ}$ - powiązanie wkładu z przełomowością transformacji TETIP („ojcowie” energetyki WEK-PK, elektryfikacji i cyfryzacji nie musieli „odbierać” nikomu rynków, byli zobowiązani tworzyć całkowicie nowe rynki; w transformacji TETIP pretendenci muszą stworzyć cztery nowe rynki elektroprosumeryzmu, za pomocą których odbiorą rynki końcowe energii elektrycznej, ciepła i paliw transportowych podmiotom zasiedziałym w całej energetyce WEK-PK).

\section{Co muszą wiedzieć siły polityczne w Polsce o elektroprosumeryźme z punktu widzenia własnego interesu?}

Władza

- samorządowa, państwowa, unijna, i pretendenci do przywództwa globalnego nie musi rozumieć tripletu paradygmatycznego monizmu elektrycznego, ale elektroprosumentów musi mieć za sobą.

8. O ile reforma polskiej elektroenergetyki zapoczątkowana na przełomie dekad przedostatniej i ostatniej XX wieku miała charakter ustrojowy (celem było wyprowadzenie elektroenergetyki z porządku socjalistycznego, ze strefy oddziaływania ZSRR), o tyle transformacja TETIP do elektroprosumeryzmu ma charakter cywilizacyjny (jej celem jest zastapienie wielkoskalowej energetyki korporacyjnej paliw kopalnych elektroprosumeryzmem i pozostanie w UE oraz w nurcie megatrendów.

9. Wejście Polski w roku 2000 na ścieżkę recentralizacji elektroenergetyki (utworzenie PKE - Południowego Koncernu Energetycznego) oznaczające systemowe (polityczne) odejście od linii programowej reformy ustrojowej w elektroenergetyce, doprowadziło w ciagu dwóch dekad do zapaści oznaczającej niezdolność całej polskiej energetyki WEK-PK do włączenia się w nurt przyspieszającej transformacji europejskiej i światowej. 
10. W zaistniałej sytuacji historycznym zadaniem każdej siły politycznej ubiegającej się o władzę (w Polsce: partia, ruch społeczny, samorząd) jest na progu roku 2021 przedstawienie w wypadku energetyki programu reformy (koncepcję trzeba już mieć, na jej poszukiwanie jest za późno). Przy tym musi to być program, który będzie realizowany w każdym kolejnym roku, w każdym okresie wyborczym, w kolejnych perspektywach budżetowych 2027, 2033, ..., 2052) Unii Europejskiej oraz w kolejnych ramach programowych (2030, 2040, 2050) Agendy 2050 UE (neutralność klimatyczna, Europejski Zielony Ład).

11. Dostępna już autorska koncepcja transformacji TETIP, z jej jądrem w postaci elektroprosumeryzmu, rozwijana i konsolidowana w ciagu ostatnich 14 lat w ramach Konwersatorium Inteligentna Energetyka, a w ciagu ostatnich 3 lat na Powszechnej Platformie Transformacyjnej Energetyki 2050 (PPTE2050) [1], jest ugruntowaną koncepcja bazującą na trzech paradygmatach (prosumenckim, egzergetycznym i wirtualizacyjnym), zweryfikowaną w ramach wszechstronnych badań modelowych.

12. Badania te w pełni uwiarygodniają hipotezę o 6-krotnie większej wydajności elektroprosumeryzmu względem rynków energii pierwotnej (energii chemicznej węgla, ropy naftowej, gazu oraz jądrowej w wypadku paliw jądrowych) oraz 3-krotnie większej wydajności względem rynków końcowych (energii elektrycznej, ciepła i paliw transportowych) posiadanych przez podmioty „zasiedziałe” - przedsiębiorstwa korporacyjne w energetyce WEK-PK - na mocy (w zakresie) koncesji rządowych (wydawanych przez Urząd Regulacji Energetyki - URE).

13. Potwierdzona w badaniach modelowych (symulacyjnych) dojrzałość autorskiej koncepcji umożliwia już przejście do opracowania politycznego (praktycznego) programu reformy energetyki wolnego od ryzyka długoterminowego, którego nie dałoby się kompensować w trybie nadążnym - umożliwiającym bieżącą reakcję na rozwój technologiczny, na dynamikę procesów społecznych oraz na nierównowagę środowiskową (przede wszystkim na zmiany klimatyczne). Uwolnienie od ryzyka gwarantuje w tej koncepcji triplet paradygmatyczny, określający ramy fundamentalne transformacji TETIP. 
14. Transformacja TETIP oznaczająca wejście w ciagu trzech dekad na drogę budowy dojrzałego elektroprosumeryzmu daje w Polsce możliwość wykorzystania przez pretendentów renty zacofania, spowodowanej w ciagu ostatnich dwóch dekad przez sojusz polityczno-korporacyjny (od roku 2015 jest to już sojusz partyjno-korporacyjny). Przede wszystkim daje jednak szansę nawiązania równorzędnych relacji z resztą świata we wspólnej przestrzeni gospodarczej, społecznej oraz środowiskowej, a w wypadku strefy euro-atlantyckiej - również we wspólnej przestrzeni kulturowej.

15. Istotą innowacji przełomowej jest zawsze - nie tylko w wypadku energetyki - wytworzenie nowych rynków, którymi pretendenci są w stanie zastapić rynki stare będące w posiadaniu podmiotów zasiedziałych (w energetyce są to korporacje, które posiadaja schodzące rynki końcowe energii elektrycznej, ciepła i paliw transportowych na mocy koncesji URE czyli rządowych).

16. Nowymi rynkami, które muszą zdobyć pretendenci, są wschodzące rynki elektroprosumeryzmu. W Polsce są to cztery główne rynki zbudowane sukcesywnie przez pretendentów: zdecentralizowany rynek energii elektrycznej 1 - funkcjonujący na lokalnej infrastrukturze sieciowej nN-SN-110kV; bezsieciowy rynek urządzeń, elektrotechnologii, materiałów; bezsieciowy rynek usług elektroprosumenckich; rynek energii elektrycznej 2 - morskiej energetyki wiatrowej.

17. Zaistniałe już w wyniku rewolucji cyfrowej globalne zmiany społeczne i osiagnięty już globalny poziom technologiczny w dziedzinie źródeł wytwórczych (odnawialnych źródeł energii, OZE), systemów magazynowania energii i zarządzania w procesach jej użytkowania spowodował, że potencjalnymi pretendentami do pierwszych trzech polskich rynków elektroprosumeryzmu na progu roku 2021 r. są:

$1^{\circ}$ - elektroprosumenci - obecnie odbiorcy energii elektrycznej, wszyscy, czyli 18 mln (od przeciętnego Kowalskiego po KGHM i PKP Energetyka), z których każdy rocznie zużywa 2,5 TWh, co razem stanowi 4\% zużycia krajowego;

$2^{\circ}$ - dalej zaś przedsiębiorcy sektora mikro, małych i średnich przedsiębiorstw (MMŚP) -2 mln potencjalnych pretendentów-innowatorów, z udziałem w PKB przekraczającym już ponad 50\%, zainteresowanych zdobyciem trzech nowych 
rynków elektroprosumeryzmu, od których zależy przejście sektora w nowy etap rozwoju, adekwatny do wymagań trzeciej dekady XXI wieku);

i wreszcie

$3^{\circ}$ - samorządy - 2,5 tys. jednostek samorządu terytorialnego (JST), zarówno w roli związanej z realizacja zadań własnych, jak i zobowiązanych do realizacji zasady pomocniczości.

18. Elektroprosumeryzm jest fundamentalną konsekwencją procesów społecznych i praw fizyki. Rynki elektroprosumeryzmu oznaczające praktyczne wygaszenie (nie tylko w Europe, ale również globalnie) energetyki WEK-EP w horyzoncie roku 2050 zapewniają elektroprosumeryzmowi w kolejnych dekadach obecnego wieku status taki, jaki miały w ostatnich 300 latach kolejno: rewolucje przemysłowe, elektryfikacja i rewolucja cyfrowa. Górnictwo węgla kamiennego było siłą rewolucji przemysłowej XIX wieku. Transport kolejowy miał do czasów elektryfikacji (do końca XIX wieku) jako paliwo wyłącznie węgiel. A dla transportu samochodowego (drogowego) paliwem do końca XX wieku była prawie wyłącznie ropa naftowa. Elektryfikacja stała się główną siłą napędową rewolucji przemysłowych na początku XX wieku, kiedy była realizowana wyspowo w trybie „prosumenckim”, w postaci elektrowni przemysłowych, które zrewolucjonizowały przemysł w stosunku do przemysłu wieków XVIII i XIX (produkcja fabryczna, przemysły włókienniczy, metalurgiczny). Następnie sukcesywnie, w miarę powstawania krajowych i kontynentalnych systemów elektroenergetycznych (SEE) elektryfikacja doprowadziła do korporatyzacji o niebywałej sile politycznej, mającej podstawę w monopolu i zawłaszczeniu pojęcia „bezpieczeństwo energetyczne”. W ostatnich czterech dekadach XX wieku oraz dwóch dekadach XXI wieku siłą napędową zmian społecznych, a sukcesywnie także gospodarki, stawała się rewolucja cyfrowa, całkowicie zmieniająca model rozwojowy świata. Cyfryzacja przyspieszyła skomplikowane, silnie wzajemnie uwarunkowane procesy: zniewolenia jednostek i społeczeństw, demokracji „,bezpośredniej” („partycypacyjnej”), niepohamowanego konsumpcjonizmu - skutkując rabunkową eksploatacją zasobów przyrodniczych.

19. W takiej przełomowej sytuacji elektroprosumeryzm, następujący po rewolucjach przemysłowych, elektryfikacji i po rewolucji cyfrowej, ma w świecie procesów społecznych swoją „własną” siłę polityczną, lokująca się ponad interesami obecnych „,nominalnych" sił politycznych (partii, samorządów oraz ruchów społecznych). 
20. Dodatkowo siła ta polega na tym, że w porównaniu z hermetyczną („elitarną”, korporacyjna) energetyką WEK-EP, elektroprosumeryzm jest bardzo prosty. Przede wszystkim na poziomie metody; przy tym ta prostota przenosi się na rozwój technologiczny oraz na rynkowe zastosowania nowych technologii, co zapewnia mu wpływ na kształtowanie procesów społecznych.

21. Na poziomie metody (choć nie tylko na tym) o prostocie elektroprosumeryzmu decyduje dodatkowo jego skalowalność, prawie taka, jak technologii świata cyfrowego. Fakt, że jadrem tej skalowalności jest człowiek - od „singla” (z mieszkaniem na swoją miarę), do 7 mld ludzi na świecie (z wszystkimi jego problemami makro: ekonomicznymi, społecznymi, środowiskowymi) - daje elektroprosumeryzmowi wielowymiarową siłę ufundowana na humanizmie, najtrwalszej i najbardziej stabilnej przestrzeni ludzkich wartości.

22. Jeśli do wymienionych przewag elektroprosumeryzmu (punkty 19-21) dołożyć jego przewagi wynikające z praw fizyki (analiza egzergetyczna $\rightarrow$ efektywność energetyczna oraz inteligentna infrastruktura $\rightarrow$ zasada współużytkowania zasobów systemów SSE), to zrozumiałe staje się, że politycy (wszystkie siły polityczne) mogą nie rozumieć tripletu paradygmatycznego monizmu elektrycznego, ale nie mogą go ignorować. Muszą się z nim liczyć, jeśli grają o miejsce w historii. Jeśli nie - muszą przegrać.

23. Elektroprosumeryzm kształtuje współcześnie wymagania kierowane w stronę sił politycznych, nie odwrotnie. Zatem historycznie znalazły się one w sytuacji polegającej na tym, że moga ogłaszać każdy pomysł na transformacje energetyki (transformacje TETIP) pod warunkiem, że jest to elektroprosumeryzm.

\section{Siła polityczna elektroprosumeryzmu i jej poręczność oraz niedogodność dla sił politycznych w Polsce}

„Otóż niezbędnym jest dla księcia, który pragnie się utrzymać, aby potrafił nie być dobrym i zależnie od potrzeby, posługiwał się lub nie posługiwał dobrocią" Niccolo Machiavelli (Ksiq̨że)

24. Dzięki skalowalności elektroprosumeryzmu, jego koncepcję można już w roku 2021 skierować w Polsce selektywnie do ponad 12 mln gospodarstw domowych, a w ten sposób 
do 38 mln mieszkańców, czyli też do 30 mln wyborców. Ale też do 18 mln odbiorców energii elektrycznej. A w wypadku tego zbioru siły polityczne muszą mieć na względzie, że jest w nim 6 mln odbiorców (a ściślej - umów o dostawę energii elektrycznej), którzy występuja po raz drugi w roli wyborców (bo po raz pierwszy występują w zbiorze 12 mln gospodarstw domowych). Przede wszystkim są to: przedsiębiorcy, łącznie (pośrednio) z zatrudnionymi w sektorze mikro, małych i średnich przedsiębiorstw - ok. 3 mln osób, dalej są wszystkie inne przedsiębiorstwa (wielki przemysł, duża część infrastruktury krytycznej itd.) - razem, poza sektorami energetyki WEK-PK, również ok. 3 mln osób.

25. Możliwość skierowania koncepcji elektroprosumeryzmu do całego społeczeństwa (kwestia interesu społecznego), do wszystkich elektroprosumentów (interesy indywidualne) i do wszystkich wyborców równocześnie (chociaż selektywnie), stanowi siłę polityczna elektroprosumeryzmu, która nie dla wszystkich interesariuszy (nie dla każdej siły politycznej) jest wygodna. Jednakże ani to, ani brak możliwości zrozumienia tripletu paradygmatycznego monizmu elektrycznego, nie dyskwalifikują interesariuszy całkowicie w walce o władzę - jeśli tylko „objawowo” siłę polityczną elektroprosumeryzmu wyczuwają i są gotowi ją respektować.

26. Jest to warunek minimum dla interesariuszy zaawansowanych w „oszukańczych” grach politycznych charakterystycznych dla przeszłości (nie tylko w Polsce). W naszym kraju w roku 2021 respektowanie realnej siły politycznej elektroprosumeryzmu polega między innymi na tym, że każda siła polityczna (partia, samorząd, ruch społeczny) musi jeśli chce wygrywać walkę o władzę - odwrócić się (być „niedobra”) od energetyki WEK-PK, ale również od dilerskich (narkotycznych) systemów wsparcia wybranych segmentów elektroprosumeryzmu (np. fotowoltaiki - PV), zapewniających rządzącym doraźny zysk polityczny, a blokujących równocześnie inne segmenty (np. lądowa energetyka wiatrowa, ustawa $10 \mathrm{H}$ ). Musi być „dobrą” dla wszystkich fundamentalnych rozwiązań elektroprosumeryzmu, będących w Polsce w roku 2021 racją stanu. I przyłączyć się do unijnej Agendy 2050, tak jak 20 stycznia 2021 roku do paryskiego porozumienia z roku 2015 (COP21) [2] przyłączyła się ponownie Ameryka (USA).

27. Siła polityczna elektroprosumeryzmu w Polsce w roku 2021 jest nie na rękę (w czasie dokonującego się przełomu), chociaż realnie w bardzo ograniczonym zakresie, sojuszowi 
partyjno-korporacyjnemu chroniącemu sektor WEK-PK, posiadający łącznie nie więcej niż 0,3 mln zatrudnionych bezpośrednio. Zatrudnionych mających oczywiście rodziny, co powoduje potrzebę systemów osłonowych, ale racjonalnych, ukierunkowanych na lokalne zielone miejsca pracy. Taki jest Unijny Fundusz Sprawiedliwej Transformacji i trzeba wszystko zrobić, aby żadna siła polityczna w Polsce nie przejęła go dla własnych celów, nie spełniających kryteriów tripletu paradygmatycznego monizmu elektrycznego. Chodzi tu zwłaszcza o finansowanie na poziomie centralnym korporacyjnych megaprojektów OZE.

28. A wracając do liczby 0,3 mln zatrudnionych w sektorze WEK-PK - w każdej odpowiedzialnej grze politycznej (jeśli już nie w przestrzeni etycznej przekonań, to przynajmniej w przestrzeni etycznej odpowiedzialności) wymaga ona w świetle czterech rynków elektroprosumeryzmu rewizji (zmniejszenia). Mianowicie, rynki elektroprosumeryzmu są bardzo na rękę zatrudnionym w podsektorze dystrybucyjnym elektroenergetyki WEK-PK (realnie nie mniej niż 50 tys. zatrudnionych). Pod warunkiem, że rządzący odważą się wprowadzić zasadę współużytkowania zasobów krajowego systemu elektroenergetycznego (KSE), fundamentalnie niezwykle potrzebną.

29. Odziaływanie polityczne elektroprosumeryzmu jest nie na rękę siłom politycznym (partiom, samorządom, ruchom społecznym) dążącym do polexitu (nie więcej niż 20\% wyborców). Z drugiej strony nawet w tym wypadku (kontekst polexitu) jest bardzo na rękę, o ile siła polityczna dąży do poszerzania przestrzeni wolności gospodarczej. Ale musi to być oczywiście siła rozumiejąca, „wyczuwająca” siłę pierwszych trzech rynków elektroprosumeryzmu w tym poszerzaniu, mianowicie rynku energii elektrycznej 1 oraz dwóch rynków bezsieciowych: urządzeń i usług.

30. Oddziaływanie polityczne elektroprosumeryzmu generalnie jest bardzo na rękę każdej sile politycznej (partii, samorządowi, ruchowi społecznemu) dążącej do tego, co rynki elektroprosumeryzmu (łącznie z czwartym rynkiem offshore) moga zapewnić. A moga radykalnie obniżyć zagrożenia środowiskowe (pobudzić wzrost efektywności energetycznej), mocno zainspirować rozwój gospodarczy, ukierunkować procesy społeczne na wzrost siły demokracji (za pomoca kapitału społecznego o bezcennej obecnie wartości dla przyszłości Polski). 
31. Siła polityczna elektroprosumeryzmu - wynikająca z jego pierwszych trzech rynków - w specjalny sposób objawia się (w perspektywie interesów sił politycznych) na obszarach, na których rynek energii elektrycznej 1 może być autonomizowany, sukcesywnie, względem systemu KSE kolejno na poziomach napięciowych sieci elektroenergetycznych: nN, SN oraz $110 \mathrm{kV}$. W Polsce są to obszary wiejskie z miastami do 500 tys. mieszkańców, ogółem około 30 mln ludności (80\% ludności Polski).

\section{Siła elektroprosumeryzmu w zarządzaniu efektywnością energetyczną} na całej trajektorii transformacji TETIP (2050) na poziomie makroekonomicznym

32. Fundamentalny ranking strategicznych działań zapewniających właściwą dynamikę rozwoju wschodzących rynków elektroprosumeryzmu jest w Polsce oraz praktycznie w skali globalnej, w kontekście efektywności energetycznej (tripletu paradygmatycznego monizmu elektrycznego), następujący:

33. Pasywizacja budynków (zasobów mieszkaniowych). Potencjał pasywizacji w zakresie efektywności energetycznej to (w przybliżeniu) 5-krotne zmniejszenie zapotrzebowania na ciepło grzewcze; z obecnej (rok 2019, przed pandemią COVID-19) wartości rocznej netto 160 TWh do 30 TWh w elektroprosumeryźmie (2050). Jest to potencjał w pełni realizowalny dla istniejących technologii i materiałów termomodernizacyjnych oraz zasobów ludzkich/biznesowych (firm sektora MMŚP).

34. Elektryfikacja ciepłownictwa. Potencjał elektryfikacji ciepłownictwa to (w przybliżeniu) 3-krotnie mniejsza energia elektryczna potrzebna do napędu pomp ciepła w porównaniu z łącznym zapotrzebowaniem na ciepło grzewcze po pasywizacji oraz na ciepło potrzebne do produkcji ciepłej wody użytkowej. Roczna wartość potrzebnej energii elektrycznej napędowej netto to $20 \mathrm{TWh}$, w porównaniu z roczną wartością netto ciepła grzewczego po pasywizacji (30 TWh) i roczną wartością netto ciepła do produkcji ciepłej wody użytkowej, równej również 30 TWh. Potencjał elektryfikacji ciepłownictwa jest w pełni realizowalny w horyzoncie 2050 dla istniejącego już poziomu technologicznego pomp ciepła i poziomu inteligentnej infrastruktury do zarządzania procesem użytkowania ciepła produkowanego przez pompy ciepła, w tym do zarządzania mikrośrodowiskiem domu pasywnego. 
35. Elektryfikacja transportu. Potencjał elektryfikacji transportu to (w przybliżeniu) 3-krotnie wyższa sprawność samochodu elektrycznego w porównaniu z samochodem z silnikiem spalinowym, zapewniająca obniżenie energii napędowej potrzebnej dla transportu drogowego z obecnej rocznej energii chemicznej paliw transportowych netto równej 200 TWh do 60 TWh energii elektrycznej napędowej netto. Jest to potencjał w pełni realizowalny w horyzoncie 2050 z punktu widzenia potrzebnych wzrostów światowych zdolności wytwórczych producentów samochodów elektrycznych oraz z punktu widzenia infrastruktury potrzebnej do pełnej elektryfikacji transportu.

36. Reelektryfikacja OZE. Zastąpienie napędową energią elektryczną pochodząca z odnawialnych źródeł wszystkich potrzeb budownictwa na ogrzewanie (po pasywizacji) i produkcję ciepłej wody użytkowej (po elektryfikacji ciepłownictwa) oraz wszystkich potrzeb transportu samochodowego (drogowego) po jego elektryfikacji zwiększa zużycie rocznej energii elektrycznej netto ze 130 TWh (2019, przed pandemia COVID-19), do 175 TWh (2050), czyli tylko o 35\%. Jest to oszacowanie uwzględniające potencjał obniżki zużycia energii elektrycznej netto na obecnym rynku końcowym energii elektrycznej z rocznej wartości $130 \mathrm{TWh}$ do $95 \mathrm{TWh}$. W jednym i drugim wypadku są to heurystyki. Podkreśla się, że pierwsza z nich ma podstawy w triplecie paradygmatycznym monizmu elektrycznego. Druga jest w pełni realizowalna w horyzoncie 2050 z punktu widzenia potencjału wzrostu efektywności użytkowania energii elektrycznej głównie w przemyśle, po powszechnym przejściu na elektrotechnologie (w tym w hutnictwie) i po transformacji przemysłu do przemysłu 4.0.

37. Konsekwentna realizacja rankingu działań (punkty 33-36), zgodnego z tripletem paradygmatycznym monizmu elektrycznego, zapewnia „docelową” (rok 2050) roczną wartość (w cenach stałych, bez podatków i parapodatków) trzech pierwszych rynków elektroprosumeryzmu nie mniejszą niż $50 \mathrm{mld}$ zł (heurystyka). A rynki te w dominującej części należą do elektroprosumentów i sektora MŚP dostarczającego urządzenia i usługi. Czyli ogólnie są to rynki napędzające rozwój oddolny, bazujący na endogenicznych zasobach podażowo-popytowych.

38. Taką wartość rynków elektroprosumeryzmu trzeba rozpatrywać w perspektywie około 5-krotnej (w przybliżeniu) redukcji obecnych rocznych kosztów (bo na pewno 
nie wartości) trzech rynków końcowych energetyki WEK-PK, wynoszących w roku 2019 około 200 mld zł (łącznie z podatkami i parapodatkami). Około 1/3 tych kosztów to koszty importu paliw (głównie ropy naftowej i gazu) oraz dóbr inwestycyjnych dla podsektora wytwórczego elektroenergetyki WEK-PK i dla sektora paliw transportowych WEK-PK.

39. Obniżenie kosztów jest źródłem skumulowanej nadwyżki rynkowej na całej trajektorii TETIP wynoszącej 2 bln zł. Jest to dominująca korzyść beneficjentów elektroprosumeryzmu (w tym wypadku elektroprosumentów i samorządów realizujących zadania własne). Jest to realna nadwyżka możliwa do wykorzystania przez państwo oraz przez samorządy do sfinansowania swoich systemów wsparcia, w trybie podobnym do tego, który realizują niektóre kraje Unii Europejskiej.

40. W koncepcji transformacji TETIP przyjęta jest (jako zasadna, na poziomie hipotezy) następująca realokacja nadwyżki rynkowej (2 bln zł) pomniejszonej o nakłady inwestycyjne potrzebne do realizacji reelektryfikacji OZE (750 mld zł): pasywizacji i elektryfikacji ciepłownictwa - $(500+350$ mld zł, odpowiednio; elektryfikacji transportu 200 - mld zł; na systemy sprawiedliwej transformacji obszarów dotkniętych wygaszaniem energetyki WEK-PK potrzeba $200 \mathrm{mld}$ zł.

Siła elektroprosumeryzmu w zarządzaniu bezpieczeństwem energetycznym na całej trajektorii transformacji TETIP(2050) na poziomie makroekonomicznym - potrzebna REFORMA (regulacje prawne)

41. Jądrem transformacji TETIP do elektroprosumeryzmu jest rynkowe równoważenie na całej jej trajektorii dwóch procesów: schodzącego energetyki WEK-PK oraz wschodzącego elektroprosumeryzmu. Inaczej, jest to równoważenie trzech schodzących rynków końcowych (energii elektrycznej, ciepła, paliw transportowych) funkcjonujących w przestrzeni prawnej określonej przez Prawo energetyczne z 10 kwietnia 1997 roku (z ponad 120 nowelizacjami w okresie do roku 2020 z ustawami „stowarzyszonymi” o odnawialnych źródłach energii, o inwestycjach w zakresie elektrowni wiatrowych oraz o rynku mocy, zgodnie z Komentarzem z roku 2020 pod redakcją Marzeny Czarneckiej i Tomasza Ogłódka [3], mającym objętość ponad 1400 stron), rynków należących na mocy koncesji 
URE do podmiotów zasiedziałych (przedsiębiorstw korporacyjnych) energetyki WEKPK, a z drugiej strony czterech wschodzących rynków elektroprosumeryzmu (rynku energii elektrycznej 1, dwóch rynków bezsieciowych, urządzeń i usług oraz rynku energii elektrycznej offshore) sukcesywnie zdobywanych przez pretendentów (elektroprosumentów, pretendentów innowatorów, uosobiony proces społeczny w postaci trzeciej fali elektroprosumeryzmu). Podkreśla się, że rynki elektroprosumeryzmu (pretendenci) w Polsce roku 2021 nie mają żadnego statusu prawnego (nie mają odrębnych regulacji prawnych, funkcjonują w przestrzeni prawnej określonej przez Prawo energetyczne).

42. Zdefiniowanie dwóch procesów (schodzacego i wschodzącego) pociaga za sobą potrzebę strukturyzacji ich zarządzania na całej trajektorii transformacyjnej TETIP. Priorytetem w zarządzaniu dwoma procesami w naturalny sposób jest ich bezpieczeństwo, każdego osobno i łączne, we wzajemnych interakcjach. To w naturalny sposób prowadzi do zarządzania bezpieczeństwem transformacji TETIP na czterech dynamicznych ścieżkach (w czterech wymiarach). Są to:

$1^{\circ}$ - bezpieczeństwo energetyczne (rozumiane tak jak obecnie, w przestrzeni Prawa energetycznego i w przestrzeni biznesowej energetyki WEK-PK) na trzech schodzących rynkach końcowych należących do energetyki WEK-PK;

$2^{\circ}$ - adekwatność rynkowa zaopatrzenia elektroprosumentów w napędową energię elektryczną OZE na czterech wschodzących rynkach elektroprosumeryzmu (nie mających na razie żadnego statusu prawnego);

$3^{\circ}$ - proces efektywnego wdrożenia (tryb dokonany) przez siły polityczne zasady współużytkowania zasobów KSE (zasady TPA+) warunkującej przywrócenie równowagi między powszechnym interesem społecznym i zdegenerowanym interesem układów partyjno-korporacyjnych;

$4^{\circ}$ - pobudzanie (tryb ciagły) trzech fal elektroprosumeryzmu (pierwszej fali prosumenckiej, już wzbierającej; drugiej innowatorów-pretendentów, czyli samorządowej oraz biznesowej w obszarze sektora MŚP, już inicjowanej punktowo przez progresywne jednostki JST oraz innowacyjnych przedsiębiorców; i trzeciej fali pretendenta zbiorowego, czyli uosobionego procesu społecznego będącego skutkiem przejścia dwóch pierwszych fal, tego który ostatecznie uwolni Polskę od energetyki WEK-PK i zablokuje w sposób trwały powstanie energetyki WEK-OZE). 
43. Cztery ścieżki zarządzania bezpieczeństwem transformacji TETIP wymagają dostosowania przestrzeni prawnej w postaci istniejącego Prawa energetycznego do realiów procesu schodzącego oraz zbudowanie nowej przestrzeni prawnej w postaci Prawa elektrycznego dostosowanego do realiów rynkowych procesu wschodzącego, czyli do czterech rynków elektroprosumeryzmu. Przy tym czwarty rynek - energii elektrycznej offshore - jest rynkiem, którego regulacje prawne w pierwszej fazie rozwoju (bieżąca dekada) będzie w Polsce determinowany tradycyjnie rozumianym bezpieczeństwem energetycznym. Dlatego ten rynek będzie wchodził w bardzo silne interakcje z rynkiem końcowym energii elektrycznej należącym do elektroenergetyki WEK-PK.

44. Wdrożenie w horyzoncie roku 2025 (2027) przez rządzących nowego Prawa elektrycznego jest warunkiem maksymalizacji efektywności makroekonomicznej transformacji TETIP. Bez takiej ustawy (jej regulacji respektujących fundamentalne właściwości elektroprosumeryzmu) transformacja TETIP będzie realizowana jedynie na poziomie mikroekonomicznym przez elektroprosumentów, wbrew polityce energetycznej determinującej przestrzeń prawną określona przez Prawo energetyczne (będzie to „własne” tempo Polski, zwiększające dystans naszego kraju do świata).

45. W oparciu o syntetyczną (fundamentalna) perspektywę prawa elektrycznego powinny być wdrażane sukcesywnie (już od roku 2021) ustawy/regulacje „przejściowe”:

$1^{\circ}$ - ustawa o zasadzie współużytkowania zasobów KSE;

$2^{\circ}$ - stowarzyszona $z$ nią ustawa o rozdzieleniu regulacji prawnych schodzącego rynku energii elektrycznej należącego do elektroenergetyki WEK-PK oraz wschodzących rynków elektroprosumeryzmu;

$3^{\circ}$ - ustawa stowarzyszona ściśle z perspektywą nowego Prawa elektrycznego, mianowicie o URS (Urząd Regulacji Sandboxów);

$4^{\circ}$ - ustawa stowarzyszona ściśle z Prawem energetycznym, mianowicie o restrukturyzacji energetyki WEK-PK.

46. Fundamentem polskiego porządku prawnego procesu wschodzącego (przejścia do elektroprosumeryzmu w roku 2050), budowanego w optyce bezpieczeństwa obydwu procesów (również schodzącego, wygaszania energetyki WEK-PK), musi być bilans zasobów wytwórczych energii elektrycznej ze źródeł odnawialnych, mający podstawę 
w paradygmacie monizmu elektrycznego. Kanoniczny bilans dla Polski ma postać przedstawioną w tabeli 1. Potrzebne moce wynikające z tej tabeli są do roku $2050 \mathrm{w}$ naszym kraju w pełni realizowalne (potwierdziły to już całkowicie doświadczenia z obszaru praktyki biznesowej).

Tabela 1. Kanoniczny miks wytwórczy Polski po reelektryfikacji OZE (2050)

Energia Moc

[\%] [GW]

GOZ - technologie gospodarki obiegu zamkniętego (roczna zdolność przetwórcza 30-100 tys. ton odpadów) z systemami multienergetycznymi posiadającymi zdol$5 \quad 1,2$ ności regulacyjno-bilansujące na rynku energii elektrycznej

\begin{tabular}{|c|c|c|}
\hline $\begin{array}{l}\boldsymbol{\mu E B} \text { - mikroelektrownie biogazowe regulacyjno-bilansujące klasy 10-100 kW przy- } \\
\text { łączane do sieci nN }\end{array}$ & 5 & 1,2 \\
\hline $\begin{array}{l}\text { EB - elektrownie biogazowe regulacyjno-bilansujące klasy } 1 \text { MW przyłączane do } \\
\text { sieci SN }\end{array}$ & 10 & 2,5 \\
\hline $\begin{array}{l}\text { EWL - elektrownie wiatrowe klasy } 3 \mathrm{MW} \text { przyłączane do sieci SN oraz klasy } 6 \mathrm{MW} \\
\text { przyłączane do sieci } 110 \mathrm{kV}\end{array}$ & 30 & 16 \\
\hline $\begin{array}{l}\text { PV - źródła dachowe klasy do } 100 \text { kW przyłączane do sieci nN oraz "terenowe" } \\
\text { klasy do } 1 \mathrm{MW} \text { przyłączane do sieci SN }\end{array}$ & 30 & 60 \\
\hline $\begin{array}{l}\text { EWM - farmy morskie klasy } 1 \mathrm{GW} \text { (z elektrowniami klasy } 10 \mathrm{MW} \text { ) eksportujące } \\
\text { energię elektryczną do aglomeracji warszawskiej, łódzkiej, Metropolii Śląsko-Zagłę- } \\
\text { biowskiej oraz aglomeracji krakowskiej i wrocławskiej za pomocą układów dosyło- } \\
\text { wych DC-(hybrydowych DC-AC)-AC }\end{array}$ & 20 & 8 \\
\hline
\end{tabular}

47. Potrzebę rozdzielenia porządków prawnych procesów schodzącego i wschodzącego transformacji TETIP potwierdzają w dramatyczny sposób doświadczane już przez Polskę skutki dotychczasowego braku tego rozdzielenia, datujące się od roku 2005 (wejście w życie Protokołu z Kioto [4], nakładającego na państwa „rozwinięte” obowiązek ograniczenia emisji gazów cieplarnianych w perspektywie 2008-2012). Wówczas unijny porządek prawny (w postaci dyrektyw) powiązany z systemami wsparcia w Polsce na rynku energii elektrycznej został zaimplementowany do ustawy Prawo energetyczne. Skutkiem były derogacje dla elektrowni węglowych, które w wypadku elektroenergetyki WEK-PK zostały całkowicie wypaczone prze sojusz polityczno-korporacyjny w stosunku do unijnej polityki energetyczno-klimatycznej (stały się zwykłym „skokiem” na 
unijną kasę). Ponadto skutkiem był system zielonych certyfikatów OZE zawłaszczony przynajmniej w 2/3 przez elektroenergetykę WEK-PK (współspalanie oraz wielkie, zamortyzowane elektrownie wodne), co praktycznie oznaczało stratę (a w każdym razie bardzo niską efektywność 2/3 wsparcia, które w całości można szacować na około 40 mld zl).

48. Kolejne doświadczenia braku rozdzielenia porządków prawnych procesów schodzącego i wschodzącego (porządków uwzględniających długoterminowe fundamentalne uwarunkowania) są widoczne w postaci trzech ustaw stowarzyszonych z Prawem energetycznym: o odnawialnych źródłach energii, o rynku mocy i o inwestycjach w zakresie elektrowni wiatrowych.

49. Ustawa o inwestycjach w zakresie elektrowni wiatrowych (z maja 2016) zablokowała całkowicie (od roku 2017 praktycznie do zera) przyrost lądowych mocy wiatrowych, który okazał się wielką przeszkodą dla sojuszu partyjno-politycznego w elektroenergetyce WEK-PK. Otóż przyrost ten utrzymywał się w latach 2011-2016 na rocznym poziomie 0,7 GW aż do 1 GW (2015), co pozwalało „spacerkiem” osiagnać moc potrzebna w horyzoncie 2050. W dodatku przy powierzchniowej ,intensywności” tej technologii około 4-krotnie mniejszej niż w Niemczech bezwzględnie, a prawie 10-krotnie mniejszej po zracjonalizowaniu wskaźnika intensywności za pomocą liczby ludności (w Niemczech i w Polsce).

50. Ustawa o odnawialnych źródłach energii (z lutego 2015 roku) została w trybie politycznym znowelizowana (2018) po to, aby umożliwić wprowadzenie narkotycznego (znacznie „przewymiarowanego”) systemu wsparcia źródeł PV. W rezultacie w sposób sztuczny przyspieszony został roczny wzrost mocy tych źródeł aż do $1 \mathrm{GW}$ w roku wyborczym 2019 i do 1,3 GW w roku wyborczym 2020. Pobudzenie tak gwałtownego przyrostu mocy w latach 2019 i 2020 było w Polsce działaniem politycznym, skierowanym całkowicie przeciw tripletowi paradygmatycznemu.

51. Ustawa o rynku mocy (z grudnia 2017) wprowadzona pod pretekstem ochrony długoterminowego bezpieczeństwa energetycznego (w porządku ustrojowym energetyki usankcjonowanym obowiązującym Prawem energetycznym) doprowadziła do wzrostu 
cen energii elektrycznej w Polsce od początku roku 2020 w czasie, kiedy w Unii Europejskiej zaczyna działać zdecentralizowany rynek bilansujący „sprowadzony” do wymiaru lokalnego (do mocy źródeł o dolnej granicy $1 \mathrm{MW}$, przyłączonych do sieci SN), źródeł i systemów charakterystycznych dla Zielonego Ladu (elektroprosumeryzmu), a nie dla bloków węglowych. Polski rynek mocy jest drastycznym przykładem odcięcia Polski - z powodu interesu partyjno-korporacyjnego elektroenergetyki WEK-PK - od korzyści transformacji energetyki zgodnej z Agendą rozwojową UE 2050 [4]. Przykładem tych korzyści (jednym z bardzo wielu) jest osiagnięty wielki spadek cen hurtowych energii elektrycznej w Niemczech w roku 2020, mianowicie o 20\% (cena w roku 2019 wynosiła $37,5 €$, a w $2020-30,5 €)$.

\section{Bibliografia}

[1] Powszechna Platforma Transformacyjna Energetyki 2050, http://www.ppte2050.pl

[2] The Paris Agreement, United Nations, 2015, https://unfccc.int/sites/default/files/english_paris_agreement.pdf

[3] Prawo energetyczne. Ustawa o odnawialnych źródłach energii. Ustawa o rynku mocy. Ustawa o inwestycjach w zakresie elektrowni wiatrowych. Komentarz, 2020, (red.) Marzena Czarnecka, Tomasz Ogłódek, Wydawnictwo C.H.Beck, Warszawa

[4] Protokół z Kioto do Ramowej Konwencji Narodów Zjednoczonych w sprawie zmian klimatu, sporządzony w Kioto dnia 11 grudnia 1997 r., Dz.U. 2005 nr 203 poz. 1684, http://isap.sejm.gov.pl/isap.nsf/DocDetails.xsp?id=wdu20052031684 